\title{
Economics of Integrated Nutrient Management in Sweet Corn (Zea mays L. saccharata sturt.)
}

\author{
Prashant N. Karanjikar*, Bhairuba M. Wakchaure, \\ Rohit Y. Karde and Shivaji R. Kadhavane
}

\author{
College of Agriculture, Vasantrao Naik Marathwada Krishi Vidyapeeth, \\ Latur-413512, Maharashtra, India
}

*Corresponding author

\section{A B S T R A C T}

\section{Keywords}

Biofertilizers,

Economics,

Integrated nutrient

management,

Sweet corn,

Vermicompost,

Zea mays

\section{Article Info}

Accepted:

22 October 2020

Available Online:

10 November 2020
A field experiment was conducted during kharif season of 2019 at the Experimental Farm, Department of Agronomy College of Agriculture, Latur to study the effect of integrated nutrient management in sweet corn (Zea mays L.var. saccharata sturt). The objective of experiment was to study the effect of integrated nutrient management on sweet corn and to work out the economics of sweet corn. The experiment was laid out in a randomized block design with seven treatments and replicated thrice. The treatments were $\mathrm{T}_{1}-100 \% \mathrm{RDF}, \mathrm{T}_{2}$ - 100\% RDF + FYM @ $5 \mathrm{t} \mathrm{ha}^{-1}, \mathrm{~T}_{3}-75 \% \mathrm{RDF}+\mathrm{FYM} @ 5 \mathrm{t} \mathrm{ha}^{-1}, \mathrm{~T}_{4}-100 \% \mathrm{RDF}+$ Vermicompost@2.5 t ha ${ }^{-1}, \mathrm{~T}_{5}-75 \% \mathrm{RDF}+$ Vermicompost @ $2.5 \mathrm{t} \mathrm{ha}^{-1}, \mathrm{~T}_{6}-100 \% \mathrm{RDF}$ +FYM@5 tha ${ }^{-1}+$ Vermicompost@1.25 $\mathrm{t} \mathrm{ha}^{-1}+$ Azospirillum and $\mathrm{T}_{7}-75 \% \mathrm{RDF}+\mathrm{FYM}$ @ $5 \mathrm{t} \mathrm{ha}^{-1}+$ Vermicompost @ $1.25 \mathrm{t} \mathrm{ha}^{-1}+$ Azospirillum. The result revealed that green cob yield $\left(10621 \mathrm{Kg} \mathrm{ha}^{-1}\right)$ and green fodder yield $\left(21824 \mathrm{Kg} \mathrm{ha}^{-1}\right)$ of sweet corn were significantly highest with the application of $100 \% \mathrm{RDF}+\mathrm{FYM} @ 5 \mathrm{t} \mathrm{ha}^{-1}+$ Vermicompost @ $1.25 \mathrm{t} \mathrm{ha}^{-1}+$ Azospirillum. The protein content did not differ significantly among the treatments whereas the highest content was observed with application of $100 \% \mathrm{RDF}+\mathrm{FYM} @ 5 \mathrm{t} \mathrm{ha}^{-1}+$ Vermicompost @ $1.25 \mathrm{t} \mathrm{ha}^{-1}+$ Azospirillum. The highest net returns ( $90311 \mathrm{ha}^{-1}$ ), gross returns ( $153062 \mathrm{ha}^{-1}$ ) and B:C ratio 2.44 highest was recorded in the application of 100\% RDF + FYM @ $5 \mathrm{t} \mathrm{ha}^{-1}+$ Vermicompost @ $1.25 \mathrm{t} \mathrm{ha}^{-1}+$ Azospirillum.

\section{Introduction}

Maize (Zea mays L.) is one of the largest producing cereal crops in the world grown in more than 150 countries having 600 million ha area with 600 million tonnes of production. In India, it is cultivated on an area of 9.0 million ha with a production of 26.0 million tonnes of grain and productivity is $2710 \mathrm{~kg}$ $\mathrm{ha}^{-1}$ (Anonymous, 2017). Maize is considered as the "Queen of Cereal". Being a $\mathrm{C}_{4}$ plant, it is capable to utilize solar radiation more efficiently even at higher radiation intensity. Maize is a versatile product with uses ranging from industrial products to food preparations, as well as direct human consumption at the vegetative stage. The immature ears are used after roasting. For this, cultivars with 
enhanced sugar content are most suitable and are preferred. Out of various specialty corns, sweet corn is a mutant type with one or more recessive alleles in homozygous condition that enable the endosperm to accumulate twice the sugar content as that of seed corn. These special corn with their high market value are perfectly suitable to peri-urban agriculture. Thus, they promise higher income to maize growers. Out of the various specialty corns, sweet corn (Zea mays L.var. saccharata sturt) has a big market potential. It is a hybridized variety of maize specially bred to increase the sugar content. In addition, fodders derived after harvest may be sold, which bring additional income to the farmers. The urban people have great interest in consuming green cobs.

In sweet corn best nutritional quality depends on moisture $(72.7 \%)$ and total solids $(22.3 \%)$ comprising of carbohydrate $(81 \%)$, protein (13\%) and lipids (3.5\%). Approximately 40\% of such corn is frozen and rest canned while processing. Sweet corn is a good source of energy. About $20 \%$ dry matter is sugar, compared with only 3 percent in dent maize at green stage. It is also good source of vitamins $\mathrm{C}$ and $\mathrm{A}$. In addition to this, it is also used in the production of flavor, starch, carbohydrates, glucose, maltose, fructose and Ayurvedic medicines for making saups, vegetable and salad etc. Amongst various agricultural inputs, fertilizer is and will remain as a chief source in achieving the food production targets. For higher productivity, there is a need for the application of higher dose of fertilizers. But the increased application of high analysis fertilizers and use of high yielding cultivars demanding more secondary and micro nutrients for enhancing food grain production which resulted in their deficiencies and declined growth and productivity of crop due to continuous removal of nutrients from soil.
The mineral fertilizer has and will continue to play the key role in the augmentation of the food production in the entire world. Due to escalating cost of chemical fertilizers and objective of minimizing environmental pollution, the search of alternative source of plant nutrients is imperative. The integrated plant nutrient supply envisages conjunctive use of inorganic and organic sources of plant nutrients for crop productivity besides sustaining soil health. Application of organic materials along with inorganic fertilizers in the soil leads to sustained productivity and also vermicomposting technology involves the bio-conversion of organic waste into vermicasts and vermiwash utilizing earthworms. Vermicompost is a nutrient rich organic fertilizer and soil conditioner. By addition of vermicompost in soil it increases the soil physical, chemical as well as bio logical properties. Bio fertilizers play an important role in increasing the availability of nitrogen and phosphorus. Among several bio agent Azospirillum is known to fix atmospheric nitrogen and increases about 10$15 \%$ grain yield in maize.

\section{Materials and Methods}

\section{Experimental site}

The field experiment was conducted during kharif season of 2019-20, at Agronomy Section Farm, College of Agriculture, Latur (Maharashtra).

\section{Soil characteristics}

The soil of experimental plot was clay in texture color with good drainage. The topography of experimental field was uniform and fairly leveled. The representative soil samples from 0 to $30 \mathrm{~cm}$ depth were taken from randomly selected plots all over the experimental field before laying out the experiment. A composite soil sample of about 
half $\mathrm{kg}$ was taken and analyzed for the determination of various physical and chemical properties of soil. The data showed that the soil of experimental plot was clayey in texture with chemical composition such as low in available nitrogen (125.3kg ha ${ }^{-1}$ ), medium in available phosphorous $(18.20 \mathrm{~kg}$ $\mathrm{ha}^{-1}$ ) and very high in available potassium $\left(498.58 \mathrm{~kg} \mathrm{ha}^{-1}\right)$. The soil was moderately alkaline in reaction having $\mathrm{pH}(7.7)$.

\section{Experimental details}

The experiment was laid out in a randomized block design with seven treatments and replicated thrice. The treatments were $\mathrm{T}_{1}$ $100 \% \mathrm{RDF}, \mathrm{T}_{2}-100 \% \mathrm{RDF}+\mathrm{FYM} @ 5$ $\mathrm{t} \mathrm{ha}^{-1}, \mathrm{~T}_{3}-75 \% \mathrm{RDF}+\mathrm{FYM} @ 5 \mathrm{t} \mathrm{ha}^{-1}, \mathrm{~T}_{4}-$ $100 \% \mathrm{RDF}+$ Vermicompost @ $2.5 \mathrm{t} \mathrm{ha}^{-1}, \mathrm{~T}_{5}$ $75 \%$ RDF + Vermicompost @ $2.5 \mathrm{t} \mathrm{ha}^{-1}, \mathrm{~T}_{6}$ $100 \% \mathrm{RDF}+\mathrm{FYM} @ 5 \mathrm{t} \mathrm{ha}^{-1}+$ Vermicompost @ $1.25 \mathrm{t} \mathrm{ha}^{-1}+$ Azospirillum and $\mathrm{T}_{7}-75 \% \mathrm{RDF}+\mathrm{FYM} @ 5 \mathrm{t} \mathrm{ha}{ }^{-1}+$ Vermicompost@1.25 tha $\mathrm{ha}^{-1}+$ Azospirillum.

\section{Seed and seed treatment}

A popular sweet corn hybrid in the region, Sugar-75, which is golden yellow in colour released by M/S Syngenta India Limited, Pune, Maharashtra, was used in the present study. It is a short duration hybrid matures in 80 to 90 days and suitable for both kharif and rabi cultivation in Maharashtra. The seed are treated with Cyantraniliprole + Thiamethoxam @ $5 \mathrm{ml} \mathrm{kg}^{-1}$ seeds and bio fertilizer Azospirillum treatment was given to seed as per treatments.

\section{Manures and fertilizers}

Organic manures viz., FYM and vermicompost were applied to the respective plots ten days before sowing. The Biofertilizer Azospirillum obtained from the Biofertilizers Production Unit, VNMKV,
Parbhani was applied one day before sowing @ $10 \mathrm{ml} \mathrm{kg}^{-1}$. The FYM and vermicompost was applied uniformly to all the plots as per treatments. As per treatments, half dose of nitrogenous fertilizers and full dose of phosphatic and potassic fertilizers were applied. The next half dose of nitrogen fertilizer was applied in bands as top dressing one month after sowing. The sources of nitrogen, phosphorus and potash were urea, single super phosphate (SSP) and muriate of potash (MOP), respectively.

\section{Yield and economics}

The total weight of fresh green cobs from each net plot treatment wise was recorded after harvest and calculated as cob yield per hectare. The treatment wise weight of green plants after removal of green cobs from each net plot was recorded separately and converted into green fodder yield per hectare. The cost of cultivation for each treatment was worked out taking in prevailing market price of inputs. Similarly gross returns were calculated based on prevailing market price of the produce. The net returns $\mathrm{ha}^{-1}$ was calculated by deducting the cost of cultivation from the gross returns $\mathrm{ha}^{-1}$ basis.

\section{Results and Discussion}

\section{Green cob yield}

The green cob yield of sweet corn (Table 1) was significantly influenced by different treatments at harvest. Significantly highest green cob yield $\left(10621 \mathrm{~kg} \mathrm{ha}^{-1}\right)$ was produced by application of 100\% RDF + FYM @ $5 \mathrm{t}$ $\mathrm{ha}^{-1}+$ Vermicompost @ $1.25 \mathrm{t} \mathrm{ha}^{-1}$ + Azospirillum $\left(\mathrm{T}_{6}\right)$ which was at par with 75\% RDF + FYM @ $5 \mathrm{t} \mathrm{ha}^{-1}+$ Vermicompost @ $1.25 \mathrm{t} \mathrm{ha}^{-1}+$ Azospirillum $\left(\mathrm{T}_{7}\right)$ and found to be significantly superior over rest of treatments. 
Significantly lowest green cob yield $7846 \mathrm{~kg}$ $\mathrm{ha}^{-1}$ of sweet corn was obtained from $75 \%$ RDF + FYM @ $5 \mathrm{t} \mathrm{ha}^{-1}\left(\mathrm{~T}_{3}\right)$. Similar results were reported by Sahoo and Mahapatra (2004), Massey and Gaur (2006) and Kurne et al., (2012).

\section{Green fodder yield}

The green fodder yield of sweet corn (Table 1) was significantly influenced by different treatments at harvest. Significantly highest green fodder yield $\left(21482 \mathrm{~kg} \mathrm{ha}^{-1}\right)$ was produced by application of $\left(\mathrm{T}_{6}\right) 100 \% \mathrm{RDF}+$ FYM@5 t ha ${ }^{-1}+$ Vermicompost@1.25 $\mathrm{t} \mathrm{ha}^{-1}+$ Azospirillum which was at par with $\left(\mathrm{T}_{7}\right) 75 \% \mathrm{RDF}+\mathrm{FYM} @ 5 \mathrm{t} \mathrm{ha}^{-1}+$ Vermicompost@1.25 t ha ${ }^{-1}+$ Azospirillum and found to be significantly superior over rest of treatments. Significantly lowest green fodder yield $\left(16898 \mathrm{~kg} \mathrm{ha}^{-1}\right)$ of sweet corn was obtain from $\left(\mathrm{T}_{3}\right) 75 \% \mathrm{RDF}+\mathrm{FYM} @ 5 \mathrm{t}$ $\mathrm{ha}^{-1}$. Similar results were reported by Jadhav and Shelke (2012) and Thorat (2016).

\section{Harvest index}

Numerically the highest harvest index (33.19\%) was recorded with the application of 75\% RDF + FYM @ $5 \mathrm{t} \mathrm{ha}^{-1}$ + Vermicompost @ $1.25 \mathrm{t} \mathrm{ha}^{-1}+$ Azospirillum $\left(\mathrm{T}_{7}\right)$. The treatment 75\% RDF + FYM @ $5 \mathrm{tha}^{-1}\left(\mathrm{~T}_{3}\right)$ of sweet corn recorded lowest harvest index $(31.47 \%)$ (Table 1). These findings are in agreement with the findings obtained by Grazia et al., (2003) and Divya Sree (2012).

Table.1 Green cob yield $\left(\mathrm{kg} \mathrm{ha}^{-1}\right)$, green fodder yield $\left(\mathrm{kg} \mathrm{ha}^{-1}\right)$ and harvest index (\%) of sweet corn as influenced by different treatments at harvest

\begin{tabular}{|c|c|c|c|}
\hline Treatments & $\begin{array}{l}\text { Green cob } \\
\text { yield } \\
\left(\mathbf{k g ~ h a}^{-1}\right)\end{array}$ & $\begin{array}{c}\text { Green } \\
\text { fodder } \\
\text { yield } \\
\left(\mathrm{kg} \mathrm{ha}^{-1}\right)\end{array}$ & $\begin{array}{l}\text { Harvest } \\
\text { index } \\
(\%)\end{array}$ \\
\hline $\mathrm{T}_{1}-100 \% \mathrm{RDF}$ & 7946 & 17300 & 31.47 \\
\hline $\mathrm{T}_{2}-100 \% \mathrm{RDF}+\mathrm{FYM} @ 5 \mathrm{t} \mathrm{ha}^{-1}$ & 8570 & 18507 & 31.65 \\
\hline $\mathrm{T}_{3}-75 \%$ RDF + FYM @ $5 \mathrm{tha}^{-1}$ & 7846 & 16898 & 31.71 \\
\hline $\mathrm{T}_{4}-100 \%$ RDF + Vermicompost @ $2.5 \mathrm{t} \mathrm{ha}^{-1}$ & 8867 & 18771 & 32.08 \\
\hline $\mathrm{T}_{5}-75 \%$ RDF + Vermicompost @ $2.5 \mathrm{t} \mathrm{ha}^{-1}$ & 7866 & 17099 & 31.51 \\
\hline $\begin{array}{l}\mathrm{T}_{6}-100 \% \mathrm{RDF}+\mathrm{FYM} @ 5 \mathrm{t} \mathrm{ha}^{-1}+ \\
\text { Vermicompost @ 1.25t ha } \mathrm{ha}^{-1}+\text { Azospirillum }\end{array}$ & 10621 & 21482 & 33.08 \\
\hline $\begin{array}{l}\mathrm{T}_{7}-75 \% \text { RDF }+ \text { FYM @ } 5 \mathrm{tha}^{-1}+ \\
\text { Vermicompost } \\
\text { @ } 1.25 \mathrm{t} \mathrm{ha}^{-1}+\text { Azospirillum }\end{array}$ & 9596 & 19312 & 31.47 \\
\hline $\mathrm{SE} \pm$ & 568 & 868 & - \\
\hline CD at $5 \%$ & 1751 & 2675 & - \\
\hline General Mean & 8759 & 18450 & 31.84 \\
\hline
\end{tabular}


Table. 2 Cost of cultivation $\left(\mathrm{Rs} \mathrm{ha}^{-1}\right)$, gross monetary returns ( $\mathrm{Rs} \mathrm{ha}^{-1}$ ), net monetary returns (Rs $\left.\mathrm{ha}^{-1}\right)$, and benefit cost ratio of sweet corn as influenced by different treatments at harvest

\begin{tabular}{|c|c|c|c|c|}
\hline Treatments & $\begin{array}{c}\text { GMR } \\
\left(\text { Rs ha }^{-1}\right)\end{array}$ & $\begin{array}{c}\text { Cost } \\
\text { cultivation } \\
\left(\text { ha }^{-1}\right)\end{array}$ & $\begin{array}{c}\text { NMR } \\
\left(\text { Rs ha }^{-1}\right)\end{array}$ & $\begin{array}{l}\text { B:C } \\
\text { ratio }\end{array}$ \\
\hline $\mathrm{T}_{1}-100 \% \mathrm{RDF}$ & 115128 & 57651 & 57477 & 2.00 \\
\hline $\mathrm{T}_{2}-100 \% \mathrm{RDF}+\mathrm{FYM} @ 5 \mathrm{tha}^{-1}$ & 124088 & 58312 & 65776 & 2.13 \\
\hline $\mathrm{T}_{3}-75 \%$ RDF + FYM @ $5 \mathrm{t} \mathrm{ha}^{-1}$ & 113579 & 57102 & 56696 & 1.99 \\
\hline $\mathrm{T}_{4}-100 \% \mathrm{RDF}+$ Vermicompost @ $2.5 \mathrm{tha}^{-1}$ & 128199 & 59262 & 68937 & 2.16 \\
\hline $\mathrm{T}_{5}-75 \% \mathrm{RDF}+$ Vermicompost @ $2.5 \mathrm{tha}^{-1}$ & 113949 & 58263 & 55683 & 1.96 \\
\hline $\begin{array}{l}\mathrm{T}_{6}-100 \% \mathrm{RDF}+\mathrm{FYM} @ 5 \mathrm{tha}^{-1}+ \\
\text { Vermicompost @ 1.25t ha } \mathrm{ha}^{-1}+\text { Azospirillum }\end{array}$ & 153062 & 62751 & 90311 & 2.44 \\
\hline $\begin{array}{l}T_{7}-75 \% \text { RDF + FYM @ } 5 \mathrm{tha}^{-1}+ \\
\text { Vermicompost @ } 1.25 \mathrm{ha}^{-1}+\text { Azospirillum }\end{array}$ & 138238 & 60132 & 78106 & 2.30 \\
\hline $\mathrm{SE} \pm$ & 7670 & - & 7670 & - \\
\hline CD at $5 \%$ & 23631 & - & 23631 & - \\
\hline General Mean & 126606 & 59068 & 67538 & 2.0 \\
\hline
\end{tabular}

\section{Economics}

\section{Gross monetary returns}

The gross monetary return (Table 2) was significantly influenced by different treatments. Significantly the highest gross monetary returns (Rs $153062 \mathrm{ha}^{-1}$ ) was recorded by application of $100 \% \mathrm{RDF}+\mathrm{FYM}$ @ $5 \mathrm{t} \mathrm{ha}^{-1}+$ Vermicompost @ $1.25 \mathrm{t} \mathrm{ha}^{-1}+$ Azospirillum $\left(\mathrm{T}_{6}\right)$ which was at par with $75 \%$ RDF+FYM@5 t ha ${ }^{-1}+$ Vermicompost @ $1.25 \mathrm{t} \mathrm{ha}^{-1}+$ Azospirillum $\left(\mathrm{T}_{7}\right)$ and found superior over rest of treatments.

Significantly lowest gross monetary returns (Rs $113579 \mathrm{ha}^{-1}$ ) of sweet corn was recorded from application 75\% RDF + FYM @ $5 \mathrm{t} \mathrm{ha}^{-1}$ $\left(\mathrm{T}_{3}\right)$.

\section{Net monetary returns}

The highest net monetary returns (Rs 90311 $\mathrm{ha}^{-1}$ ) (Table 2) was recorded by application of of $100 \%$ RDF + FYM @ $5 \mathrm{tha}^{-1}+$ Vermicompost@1.25 t ha ${ }^{-1}+$ Azospirillum $\left(\mathrm{T}_{6}\right)$.The lowest net monetary return (Rs
$55683 \mathrm{ha}^{-1}$ ) of sweet corn was recorded from 75\% RDF + FYM @ $5 \mathrm{tha}^{-1}\left(\mathrm{~T}_{3}\right)$.

The economics results are in accordance with the findings Kumar and Thakur (2004), Jadhav and Shelke (2012).

Based on the result it can be concluded that significantly higher yield and net returns were produced by application of 100\% RDF + FYM@ $5 \mathrm{t} \mathrm{ha}^{-1}+$ Vermicompost @ 1.25 $\mathrm{tha}^{-1}+$ Azospirillum.

\section{Acknowledgement}

The authors gratefully acknowledge the College of Agriculture, VNMKV, Latur, Maharashtra, who permitted to carry out this research work by using all the facilities available.

\section{References}

Anonymous, 2017. Season-wise Area, Production, Productivity of Maize Indahttps://www.indiastat.com/table/agr iculturedata/2/agriculturalproduction//2 
25/7269/data.aspx.

Divya Sree (2012). Integrated nutrients management in sweet corn (Master's thesis). Acharya N. G. Ranga Agricultural University.

Grazia J. D., Tittonell, P.A., Germinara, D. and A. Chiesa 2003. Phosphorus and nitrogen fertilization in sweet corn ( $\mathrm{Zea}$ mays L. var. saccharata Bailey). Journal of Agricultural Research, 1(2): 103-107.

Jadhav V.T. and Shelke, D.K.. (2012). Effect of planting methods and fertilizer levels on growth, yield and economics of maize (Zea mays L.) Hybrids. Journal of Agricultural Research and Technology, 37(1): 011-014.

Kumar A. and Thakur, K. S. (2007). Effect of integrated nutrient management on promising composite maize (Zea mays L.) varieties under rainfed mid-hill conditions of Himachal Pradesh. Indian Journal of Agricultural Science, 74 (1) 40-42.
Kurne, R.A., Jadhav, Y. R., and Mohite, A. B. (2017). Effect of fertilizer levels and plant densities on growth, productivity and economics of sweet corn in summer season. Contemporary Research in India, 7(3): 2231-2237.

Massey, J.X. and Gaur, B. L. (2001). Effect of plant population and fertility levels on yield attributes, yield and nutrient uptake of sweet corn (Zea mays L.) cultivars. Advance Research Journal of Crop improvement, 4(1): 34-37.

Sahoo S.C. and Mahapatra, P. K. (2004). Response of corn to nitrogen levels and plant population. Indian Journal of Agricultural Science, 74(6): 337-338.

Thorat K. S., (2016). Response of sweet corn to different fertilizers levels and spacing in kharif season. Thesis submitted for M.Sc. (Agri.) degree to Vasantarao Naik Marathwada Krishi Vidyapeeth, Parabhani.

\section{How to cite this article:}

Prashant N. Karanjikar, Bhairuba M. Wakchaure, Rohit Y. Karde and Shivaji R. Kadhavane. 2020. Economics of Integrated Nutrient Management in Sweet Corn (Zea mays L. saccharata sturt.). Int.J.Curr.Microbiol.App.Sci. 9(11): 3016-3021.

doi: https://doi.org/10.20546/ijcmas.2020.911.365 